\title{
THE DYNAMIC OF HEART RATE VARIABILITY UNDER THE PHYSICAL REHABILITATION PROCESS IN OFFICE WORKERS WITH LOW BACK PAIN
}

\author{
Volodymyr Kormiltsev
}

\begin{abstract}
Резюме. За допомогою аналізу варіабельності серцевого ритму експериментально підтверджено ефрективність програми фрізичної реабілітації попереково-крижового остеохондрозу у офрісних співробітників У дослідженні взяли участь 60 осіб віком 38,6 років. Показано позитивний вплив на характер серцевого ритму програми фрізичної реабілітації з елементами медфріту, лікувального масажу, гідрокінезитерапії та засобів, запозичених з оздоровчого фрітнесу. Встановлено, що позитивний вплив програми залежить від адекватно підібраних засобів і методів відновлення функціонального стану. Ключові слова: офрісні співробітники, фрізична реабілітація, попереково-крижовий остеохондроз, варіабельність серцевого ритму.
\end{abstract}

Summary. There was proposed and experimentally verified the effectiveness of physical rehabilitation program of low back pain in office workers through the analysis of heart rate variability. In the research take part 60 people, an average age is 38,6 years. There is a positive effects on the heart rate has physical rehabilitation program with medfit elements, therapeutic massage, hydrokinesiotherapy and tools borrowed from healthy fitness. It was established that the positive impact of the program depends on adequately selected tools and methods restoring functional condition.

Keywords: office workers, physical rehabilitation, low back pain, heart rate variability.

Introduction. At the present stage of society development a special social significance takes a problem of preserving and strengthening of the health, maintenance of the physical condition and the prevention of various types of chronic disease in populations [6]. There are significantly increased a number of people with spinal disorders. An interest to this issue arose in connection with the vastness of the disease and the sharp need for improving disability in people suffering from low back pain (LBP). Particularly, LBP occurs in $40-50 \%$ of patients with diseases of the nervous system and 3,5\% of all patients that had applied for the first time for medical help, but by the number of lost working days a year back pain followed by influenza and household injuries [4].

Also, LBP is common among office workers. Approximately 23 to $38 \%$ of office workers experience LBP [11]. This contingent has mostly sedentary lifestyle. This component is one of the factors that increasing the development of LBP. A lack of motor activity during the working day, the constant distress and the nervous system tension in conjunction with improper working posture increases the risk of degenerative disc disease.

Analysis of recent research and publications.

Analyzing a numerous reports of basic and applied research in the field of histology, physiology, pathomorphology, biomechanics, we concluded that, in the case of an emergence and development of LBP, physical culture generally should be universal, firstly, acting preemptively on many pathogenetic links of the chain of disease at the cellular, tissue and organ levels, and secondly, encouraging reaction of a sanogenesis [3].

Recent data about the effectiveness of treatment and prevention of LBP have shown that using an integrated approach to physical rehabilitation can successfully prolong remission, stop a pain and improve quality of life and functional status of patients [10]. However, the question remains - what impact should implement as better as using of its combination with some form of the disease, depending on the clinical manifestations of LBP.

There are also many approaches regarding the establishment of progress or regression of the disease during the rehabilitation process of individuals with LBP.

The indices of cardiorespiratory system, the functional status of the musculoskeletal system and physical performance during neck pain characterizes [5]. Features of using of the fitness program in physical rehabilitation and its effect on the peripheral hemodynamics in patients with back pain describes [2].

In the work of O. I. Tyravs'ka (2008) were presented multilevel governance of violations muscle activity, also there was described the complexity of pathobiomechanical disorders during LBP, thus, 
the recovery of special motor mode is the only comprehensive method of rehabilitation that may affect both the individual links in the pathogenesis and the entire propulsion system as a whole [7].

In research of Y. Sakai [12] described that LBP caused by compression syndrome, in same time, muscle tone at rest increases and decreases for a maximum voltage.

But recent studies have been neglected dynamics of influence stress-realization factors in office workers with LBP.

The research of the wave structure of the heart rate (HR) in office workers with LBP may be the best way to prove the nature of neurogenic disorders $[1,8]$. Characteristic changes in the performance of the spectral analysis of the HR during the LBP can improve informative assessment of the autonomic nervous system and to use the analysis of heart rate variability (HRV) to oversee the process of rehabilitation.

Communication with academic programs, plans, themes. The research is performed in accordance with the scientific and research plan of the physical rehabilitation department NUPESU as a «Consolidated plan for SRW in the field of physical education and sports on a 2011-2015 years» of the Ministry of Ukraine for Family, Youth and Sports related with theme 4.4. as «An improving of organization and education foundations of physical rehabilitation programming with dysfunctional disorders in various systems of the human body». State registration number is $0111 \mathrm{U} 001737$.

Aim of this work is to evaluate the efficiency of physical rehabilitation program for office workers with LBP in remission by the means of the heart rate variability.

Methods are applied in our research is an analysis of scientific literature, HRV analysis and mathematical statistics.

Results. We were formed and studied a group of office workers (men 2 nd adult age $(n=60)$ ), directed at the rehabilitation from LBP in remission.

The condition of an autonomic nervous system is determined by the means of the HRV. The analysis of the HRV was performed by the tool and a computer program for analysis and interpretation of the electrocardiogram (ECG) as a «Fazagraf-P». The program analyzes the dynamics of changes in the functional condition of the human and displays the results in a special window for comparison of two ECG, there was current and previously stored.

An assessment of the HR character is presented in table 1.

Thus, the amplitude of mode (Amo) component of a chosen contingent was 78,1 $\pm 5,48 \%(\bar{x} \pm \mathrm{S})$, this indicates to the predominance of the moderate sympathicotonia. These data are partially confirmed
Table 1 - Average rates of HRV in men $(n=60)$

\begin{tabular}{|l|c|c|c|c|c|c|}
\hline $\begin{array}{l}\text { Investigated } \\
\text { parameters }\end{array}$ & $\bar{x}$ & $\mathbf{S}$ & $\mathbf{M e}$ & $\mathbf{2 5} \%$ & $\mathbf{7 5} \%$ & $\mathbf{v} \%$ \\
\hline Amo, \% & 78,1 & 5,48 & 78,0 & 73,3 & 82,7 & 7,1 \\
\hline LF, \% & 70,4 & 7,81 & 71,8 & 65,2 & 75,2 & 11,1 \\
\hline HF, $\%$ & 20,2 & 4,91 & 20,2 & 16,6 & 24,0 & 24,3 \\
\hline LF/ HF, \% & 3,7 & 1,09 & 3,4 & 2,9 & 4,5 & 29,4 \\
\hline SI, c.u. & 541,5 & 77,67 & 543,6 & 477,0 & 590,4 & 14,3 \\
\hline
\end{tabular}

by indices of the stress index (SI) of regulatory systems, that amounted 541,5 $\pm 77,67 \mathrm{c.u} .(\bar{x} \pm \mathrm{S})$, that indicating on the expressed sympathicotonia and a risk of short functional disorders and the damaging effect of stress on the organs of implementing systems tested. The index of sympathetic nervous system activity (LF value) was 70,4 $\pm 7,81 \%$ $(\bar{x} \pm \mathrm{S})$, index of the parasympathetic nervous system activity (HF value) was $20,2 \pm 4,91 \%(\bar{x} \pm \mathrm{S})$, that confirming the data described above. The relation $\mathrm{LF} / \mathrm{HF}$ was $3,7 \pm 1,09 \%(\bar{x} \pm \mathrm{S})$, that indicating on the temporary mobilization of the body.

Based on the received data, we have developed a physical rehabilitation program which was divided into such periods:

$\checkmark$ Adaptation period;

$\checkmark$ Training and corrective period;

$\checkmark$ Stabilization period;

$\checkmark$ All periods were identical in main group (MG) and control group (CG).

The main difference between the MG and CG was in the filling of physical rehabilitation programs, offering the recovery of functional condition tools and in the organization construction occupations.

$1^{\text {st }}$ period. The duration was 2 months, the objectives were muscle relaxation, preparation for increasing loads, contingent under the research was under partial remission. The tools used in this period were: TE, acupressure and acupuncture, hydrokinesiotherapy with elements from aquafitness.

$2^{\text {nd }}$ period. The duration was 6 months, the objectives were correction of pathological profile of a posture, muscle correction, contingent under research was at complete remission. The tools used in this period were stabilization training and corrective exercises.

$3^{\text {rd }}$ period. The duration was 6 months, the objectives were muscle strengthening and extension of the remission. The tools used in this period were training in a gym and functional training.

In the $\mathrm{MG}$ at the end of the experiment an index of Amo was $40,8 \pm 5,69 \%$, that indicating on the vegetative balance of a regulatory systems, in the CG the same index was $44,8 \pm 3,31 \%$, that is also a sign of vegetative balance $(\mathrm{p}<0,01)$. These data are supported by indices of SI. After a rehabilitation course, in the MG it was $112,1 \pm 22,77$ c.u., in the CG same index was $126,6 \pm 16,05$ c.u. 
Table 2 - The dynamics of HRV evaluation in the MG and CG $(n=60)$

\begin{tabular}{|c|c|c|c|c|c|c|c|c|c|c|}
\hline \multirow{2}{*}{$\begin{array}{l}\text { Investigated } \\
\text { parameters }\end{array}$} & \multicolumn{2}{|c|}{ MG, before $(n=30)$} & \multicolumn{2}{|c|}{ CG, before $(n=30)$} & \multirow{2}{*}{$\mathbf{p}$} & \multicolumn{2}{|c|}{ MG, after $(n=30)$} & \multicolumn{2}{|c|}{ CG, after $(n=30)$} & \multirow{2}{*}{ p } \\
\hline & $\bar{x}$ & $\mathrm{~m}$ & $\bar{x}$ & $\mathrm{~m}$ & & $\bar{x}$ & $\mathrm{~m}$ & $\bar{x}$ & $\mathrm{~m}$ & \\
\hline Amo, $\%$ & 80,1 & 6,14 & 77,4 & 4,74 & $<0,05$ & 40,8 & 5,69 & 44,8 & 3,31 & $>0,01$ \\
\hline LF, \% & 73,4 & 8,97 & 69,3 & 6,40 & $<0,05$ & 39,7 & 3,95 & 41,9 & 2,25 & $>0,01$ \\
\hline $\mathrm{HF}, \%$ & 22,2 & 4,37 & 19,4 & 5,34 & $<0,05$ & 19,6 & 3,21 & 16,5 & 5,1 & $>0,01$ \\
\hline LF/ HF, \% & 3,5 & 0,95 & 3,9 & 1,21 & $<0,05$ & 2,1 & 0,39 & 2,8 & 1,01 & $>0,01$ \\
\hline SI, c.u. & 507,6 & 91,4 & 535,9 & 62,07 & $<0,05$ & 112,1 & 22,77 & 126,6 & 16,05 & $>0,01$ \\
\hline
\end{tabular}

Also, under the influence of developed physical rehabilitation program changed the indices of regulatory body systems $(\mathrm{p}<0,01)$. In the $\mathrm{MG}$ an index of LF value fell down from $73,4 \pm 8,97 \%$ to $39,7 \pm 3,95 \%$, in the CG same final index was $41,9 \pm 2,25 \%$. An index of HF value in the both groups fell down too, and in the end of research in the MG it was $19,6 \pm 3,21 \%$, in the CG it was $16,5 \pm 5,1 \%$. Index of the $\mathrm{LF} / \mathrm{HF}$ values in the end of research in both groups felt down $(p<0,01)$, and in the MG it was $2,1 \pm 0,39 \%$, in the $C G$ it was $2,8 \pm 1,01 \%$ (table. 2 ).

Conclusions. The components of the developed physical rehabilitation program used in LBP in remission are differentiated by the intensity, volume and direction of impact on individual muscle groups, depending from the location of the affected segment, indices of the functional conditions, the nature and duration of the disease occurrence.

HRV indices analysis was statistically significant improvements in the level of tension in the regulatory systems of the body of the MG and CG. These data also indicate that results of the rehabilitation in the CG, where using standard rehabilitation complex generally has a positive effect, but less effective than in the case of our proposed rehabilitation program.

The prospect of further research. There are plans to develop a comprehensive physical rehabilitation program of LBP in the stage of full and partial remission in men.

\section{Література}

1. Бабуни И. В. Азбука анализа вариабельности сердечного ритма / И. В. Бабунц, Э. М. Мириджанян, Ю. А. Машаех. - М.: 2010. - 109 c.

2. Круцевич Т. Ю. Влияние программы физической реабилитации с использованием средств фитнеса на показатели периферической гемодинамики лиц с вертеброгенной патологией. / Т. Ю. Круцевич, Е. Б. Лазарева, С. Н. Федоренко и др. // Вісн. Запорізь. нац. ун-ту. Сер.: Фізичне виховання і спорт. - 2013. - № 1 (10). - С. 103-107.

3. Медицинская реабилитация: кн. 1 / под ред. В. М. Боголюбова. - М.: БИНОМ, 2010. - С. 6-9.

4. Павленко С. С. О необходимости стандартизации оказания медицинской помощи больным С поясничными болями / С. С. Павленко // Боль. - 2009. - № 1(22). - С. 22-25.

5. Родин С. Функциональное состояние кардиореспираторной системы при остеохондрозе шейного отдела позвоночника / С. Родин // Фіз. виховання, спорт і культура здоров'я у сучасному суспільстві: зб. наук. пр. -2010 . - № 3 (11). - С. 71-74.

6. Родионова О. Н. Остеохондроз. Лучшие методы лечения / О. Н. Родионова, Г. А. Никитина. - СПб.: Нев. проспект; Вектор, 2007. - 49 с.

7. Тиравська О. І. Методи фрізичної реабілітації в терапії дискогенного больового синдрому поперекового відділу хребта. / О. І. Тиравська // Молодіж. наук. вісн. - 2008. - № 2. - С. 48-51.

8. Яблучанский Н. И. Вариабельность сердечного ритма: в помощь практикующему врачу / Н. И. Яблучанский, А. В. Мартыненко. - Х., 2010. - 131 с.

9. Boyle K. L. Managing a male patient with left low back pain and sacroiliac joint pain with therapeutic exercise: a case report / K. L. Boyle // Physiotherapy Canada. - 2009. - Vol. 63. - P. 154-163.

10. Geisen T. Disability Management and Workplace Integration / T. Geisen, H. Harder, Gower Publishing, Ltd., 2011. - 250 p.

11. Pensri $P$. Effectiveness of brief education combined with a home - based exercise program on pain and disability of office workers with chronic low back pain: a pilot study / P. Pensri, P. Janwantanakul // J. physical therapy sci. -2012 . - N 24. - P. $217-222$.

12. Sakai Y. Low back pain pathogenesis and treatment. / Y. Sakai, Janeza Trdine, Croatia, 2012. - 256 p.

\section{References}

1. Babunc I. V. ABC of heart rate variability analysis / I. V. Babunc, E. M. Miridzhanyan, Y. A. Mashayekh. - M.: 2010. - 109 p. 
2. Krutsevych T. Y. An influence of physical rehabilitation program with the using of fitness on the performance of peripheral hemodynamics of persons with vertebral pathology / T. Y. Krutsevych, Y. B. Lazarieva, S. N. Fedorenko et al. // J. of Zaporizhzhya National University. Series: Physical Education and Sport. - 2013. - N 1 (10). - P. 103107.

3. Medical rehabilitation / Ed. by V. M. Bogolyubov. 1st ed. - M.: BINOM, 2010. - P. 6-9.

4. Pavlenko S. S. About the need for standardization of care for patients with back pain. / S. S. Pavlenko // Pain. - 2009. - N 1(22). - P. 22-25.

5. Rodin S. A functional condition of the cardiorespiratory system during the neck pain. / S. Rodin // Physical education, sport and health culture in modern society: Collected Works. - 2010. - N 3 (11). - P. 71-74.

6. Rodionova O. N. Back pain. The best methods of treatment / O. N. Rodionova, G. A. Nikitina. - SPb.: Nevsky Prospect; Vector, 2007. - 49 p.

7. Tyravs'ka O. I. Methods of physical rehabilitation in the treatment of discogenic pain in the lumbar spine I O. I. Tyravs'ka // Youth Science Bulletin. - 2008. - N 2. - P. 48-51.

8. Yabluchanskiy N. I. Heart rate variability: to help the practitioner / N. I. Yabluchanskiy, A. V. Martynenko. Kharkov, 2010. - $131 \mathrm{c}$.

9. Boyle K. L. Managing a male patient with left low back pain and sacroiliac joint pain with therapeutic exercise: a case report / K. L. Boyle // Physiotherapy Canada. - 2009. - Vol. 63 - P. 154-63.

10. Geisen T. Disability Management and Workplace Integration / T. Geisen, H. Harder, Gower Publishing, Ltd., 2011. - 250 p.

11. Pensri P. Effectiveness of brief education combined with a home - based exercise program on pain and disability of office workers with chronic low back pain: a pilot study / P. Pensri, P. Janwantanakul // Journal of physical therapy science. - 2012. - N 24. - P. 217-222.

12. Sakai Y. Low back pain pathogenesis and treatment / Y. Sakai, Janeza Trdine, Croatia, 2012. - 256 p.

Національний університет фрізичного вихованн я і спорту України, Київ

Надійшла 11.12.2013 v3rv0lf@mail.ru 